\title{
Indigenous Young People with Foetal Alcohol Spectrum Disorders: The Convention on the Rights of Persons with Disabilities and Reform to the Law Governing Fitness to Stand Trial in Western Australia
}

\author{
Rhianna Chisholm, Tamara Tulich and Harry Blagg*
}

\begin{abstract}
This article examines the place of the Convention on the Rights of Persons with Disabilities in relation to reform of Western Australian law governing fitness to stand trial, with a particular focus on Indigenous youth with Foetal Alcohol Spectrum Disorders (FASD). This article considers whether and how the Convention might be relied upon to improve outcomes for Indigenous youth with FASD, particularly through its promotion of a social model of disability. We argue that the social model of disability embodied in the Convention can only take us so far, and that many of the aspirations of the Convention regarding disability neutrality may, in fact, be counterproductive for Indigenous youth, rendering culture invisible and denying the colonial underpinnings of the disability in Indigenous communities. The Convention must be read 'in tension' with the United Nations Declaration on the Rights of Indigenous Peoples and with Indigenous knowledge. We argue that an appropriate response requires decolonising the justice system to break down the barriers that prevent Indigenous young people with FASD from participating on an equal basis. To do so, the role of colonisation in the production of impairment and disability must be acknowledged, and law reform must facilitate communityowned solutions - placing Indigenous organisations and practices at the centre, rather than the periphery, of intervention.
\end{abstract}

\section{INTRODUCTION}

Foetal Alcohol Spectrum Disorder (FASD) is an umbrella term encompassing a spectrum of disorders caused by prenatal alcohol exposure, including FASD with three sentinel features (a new diagnostic category replacing Foetal Alcohol Syndrome (FAS)) and FASD without three sentinel features (replacing the previous categories of Partial FAS (pFAS) and Neurodevelopmental Disorder-Alcohol Exposed). ${ }^{1}$ While Australian data is limited, the prevalence of FASD in Indigenous communities is

We thank the anonymous reviewers of this journal for their constructive comments on an earlier draft. All errors of course remain our own. 
indicatively greater than non-Indigenous communities. ${ }^{2}$ The issue of FASD in the West Kimberley region of Western Australia was highlighted by Bunuba women June Oscar, Emily Carter (Marninwarntikura Women's Resource Centre) and Maureen Carter (Nindilingarri Cultural Health) as part of a broader campaign to reduce alcohol consumption in Fitzroy Crossing and publicise its catastrophic effects. In 2015, rates of FAS/pFAS of 12 per 100 children were reported in Fitzroy Crossing. ${ }^{3}$ This is the highest reported prevalence in Australia. ${ }^{4}$

Young people with FASD may experience cognitive, social and behavioural difficulties, including difficulties with memory, impulse control and linking actions to consequences, making them susceptible to contact with the criminal justice system. ${ }^{5}$ When in contact with the justice system, these difficulties place young people with FASD at a disadvantage when trying to explain behaviour, instruct lawyers, give evidence, or comply with orders. ${ }^{6}$ Repeated negative contact with the justice system also raises the likelihood of young people with FASD developing 'secondary' disabilities, such as mental illness, which increases their susceptibility to further contact with the justice system (as victims and offenders). ${ }^{7}$

Justice professionals and community members in Western Australia are concerned that attention on FASD would lead to greater use of the Criminal Law (Mentally Impaired Accused) Act 1996 (WA) (CLMIA Act), which governs fitness to stand trial. ${ }^{8}$ Fitness to stand trial relates to an accused's ability to participate in trial proceedings, central to the fairness of the trial process. Each Australian jurisdiction has separate legislation governing fitness to stand trial. The Western Australian regime is

$1 \quad$ Carol Bower and Elizabeth Elliott, on behalf of the Steering Group, Australian Guide to the Diagnosis of Fetal Alcohol Spectrum Disorder (FASD) (Report to the Australian Government Department of Health, 2016).

2 House of Representatives Standing Committee on Aboriginal and Torres Strait Islander Affairs, Parliament of Australia, Doing Time - Time for Doing: Indigenous Youth in the Criminal Justice System (2011) 33.

3 James Fitzpatrick et al, 'Prevalence of Fetal Alcohol Syndrome in a PopulationBased Sample of Children Living in Remote Australia: The Lililwan Project' (2015) 51(4) Journal of Paediatrics and Child Health 450.

$4 \quad$ Ibid 450.

$5 \quad$ Heather Douglas, 'The Sentencing Response to Defendants with Foetal Alcohol Spectrum Disorder' (2010) 34(4) Criminal Law Journal 221; Natalie Novick Brown et al, 'Prenatal Alcohol Exposure: An Assessment Strategy for the Legal Context' (2015) 42-43 International Journal of Law and Psychiatry 144.

6 Legislative Assembly Education and Health Standing Committee, Parliament of Western Australia, Foetal Alcohol Spectrum Disorder: The Invisible Disability (2012) 75; Douglas, above n 5, 228.

7 Gideon Koren, 'Hypothetical Framework: FASD and Criminality: Causation or Association? The Limits of Evidence Based Knowledge' (2004) 2 Journal of FAS International $1,4$.

8 Harry Blagg et al, 'Diversionary Pathways for Indigenous Youth with FASD in Western Australia: Decolonising Alternatives' (2015) 40(4) Alternative Law Journal 257; Harry Blagg et al, 'Placing Country at the Centre: Decolonising Justice for Indigenous Young People with Foetal Alcohol Spectrum Disorders (FASD)' (2015-2016) 19(2) Australian Indigenous Law Review 4. 
controversial because it provides for indefinite detention in a custodial setting without trial of a person found unfit to stand trial for an offence carrying a term of imprisonment. A person found unfit, and thus unconvicted, can spend longer in detention than if they had pleaded guilty and were sentenced to imprisonment for the offence.

This article examines the place of the Convention on the Rights of Persons with Disabilities (CRPD) in relation to reforming laws governing fitness to stand trial, with a particular focus on Indigenous youth with FASD. The CRPD entered into force in 2008, and is the first international convention to address exclusively the rights of persons with disabilities. ${ }^{9}$ While the CRPD does not expressly create new rights for persons with disabilities, it goes further than restating existing human rights; many provisions require States to take positive action, including significant law reform, to implement the principles underlying the CRPD and protect the rights contained within it. ${ }^{10}$ Consideration of the impact of the CRPD has begun to take place in the literature, predominantly in relation to civil mental health law. ${ }^{11}$ Little consideration has been given to the impact of the CRPD on criminal law related to mental fitness. ${ }^{12}$

We argue that the social model of disability embodied in the CRPD can only take us so far, and that many of the aspirations of the CRPD regarding disability neutrality may, in fact, be counterproductive for Indigenous youth, rendering culture invisible and denying the colonial underpinnings of the disability in Indigenous communities. In doing so, our Article contributes to the growing body of literature calling for recognition of the role of colonisation in the production of impairment and disability, and critical consideration of the role of the CRPD in redressing disability injustice. ${ }^{13}$ The CRPD must, we argue, be read 'in tension'

9 Convention on the Rights of Persons with Disabilities, opened for signature 30 March 2007, 2515 UNTS 3 (entered into force 3 May 2008) (CRPD).

10 In this sense, the CRPD challenges the traditional division of rights into categories of civil and political rights ('negative' rights) and economic, social and cultural rights ('positive' rights): Peter Bartlett, 'The United Nations Convention on the Rights of Persons with Disabilities and Mental Health Law' (2012) 75(5) Modern Law Review 752, 757. See also Frédéric Mégret, 'The Disabilities Convention: Human Rights of Persons with Disabilities or Disability Rights?' (2008) 30 Human Rights Quarterly 494; Eilionóir Flynn, From Rhetoric to Action: Implementing the UN Convention on the Rights of Persons with Disabilities (Cambridge University Press, 2011).

11 See, for example, Bernadette McSherry, 'Mental Health Laws: Where to From Here?' (2014) 40(1) Monash University Law Review 175; Bartlett, above n 10, 752; George Szmukler et al, 'Mental Health Law and the UN Convention on the Right of Persons with Disabilities' (2014) 37(3) International Journal of Law and Psychiatry 245.

12 This issue has been considered in a general sense in Christopher Slobogin, 'Eliminating Mental Disability as a Legal Criterion in Deprivation of Liberty Cases: The Impact of the Convention on the Rights of Persons with Disabilities on the Insanity Defense, Civil Commitment, and Competency Law' (2015) 40 International Journal of Law and Psychiatry 36.

13 Laura Jordan Jaffee, 'Disrupting Global Disability Frameworks: SettlerColonialism and the Geopolitics of Disability in Palestine/Israel' (2016) 31(1) 
with the United Nations Declaration on the Rights of Indigenous Peoples (UNDRIP), ${ }^{14}$ which Australia endorsed in 2009, after initially voting against it. ${ }^{15}$ The UNDRIP provides for collective Indigenous rights, in contrast to the Western individualistic vision contained in many international human rights instruments. Members of the Permanent Forum on Indigenous Issues have stated:

Implementing the [CRPD] in a way that also respects the [UNDRIP] means that, whenever relevant, the measures foreseen in the [CRPD] will need to be applied in a way that is sensitive to the culture and world vision of indigenous peoples in order to best protect the rights of indigenous persons with disabilities. ${ }^{16}$

We argue that an appropriate response requires decolonising the justice system to break down the barriers that prevent Indigenous young people with FASD from participating on an equal basis. To do so, law reform must facilitate community-owned solutions - placing Indigenous organisations and practices at the centre, rather than the periphery, of intervention.

\section{THE CRPD}

The purpose of the CRPD is to "promote, protect and ensure the full and equal enjoyment of all human rights and fundamental freedoms by all persons with disabilities, and to promote respect for their inherent dignity'. ${ }^{17}$ Australia ratified the CRPD on 17 July 2008 and acceded its Optional Protocol on 21 August 2009. Australia has taken action to implement some of the principles contained in the CRPD with the introduction of the National Disability Strategy 2010-2020,18 and has already completed its initial report to the Committee on the Rights of Persons with Disabilities (Disability Committee) regarding action taken to implement the CRPD domestically. ${ }^{19}$ At the federal level, the CRPD is one of the seven core

Disability \& Society 116; Karen Soldatic, 'Postcolonial Reproductions: Disability, Indigeneity and the Formation of the White Settler State of Australia' (2015) 21(1) Social Identities 53; Karen Soldatic, 'The Transnational Sphere of Justice: Disability Praxis and the Politics of Impairment' (2013) 28(6) Disability \& Society 744.

14 United Nations Declaration on the Rights of Indigenous Peoples, GA Res 61/295, UN GAOR, 61st sess, 107th plen mtg, Supp No 49, UN Doc A/RES/61/295 (13 September 2007) (UNDRIP).

15 Megan Davis 'Indigenous Struggles in Standard-Setting: The United Nations Declaration on the Rights of Indigenous Peoples' (2008) 9(2) Melbourne Journal of International Law 239, 440.

16 Permanent Forum on Indigenous Issues, Study on the Situation of Indigenous Persons with Disabilities, with a Particular Focus on Challenges Faced with regard to the Full Enjoyment of Human Rights and Inclusion in Development, UN ESC, 12th sess, UN Doc E/C.19/2013/6 (5 February 2013) [11].

17 CRPD Art 1.

18 Commonwealth of Australia, National Disability Strategy 2010-2020 (2011).

19 Australian Government, Implementation of the Convention on the Rights of Persons with Disabilities: Initial Reports Submitted by State Parties under Article 35 of the Convention, 107th-109th mtg, UN Doc CRPD/C/AUS/1 (7 June 2012). 
human rights treaties against which the Parliamentary Joint Committee on Human Rights scrutinises Bills. ${ }^{20}$

Despite these measures, the reluctance of successive Australian governments to fully comply with the obligations contained in core international human rights instruments may limit the impact of the CRPD domestically. ${ }^{21}$ Indeed, there has been no action following the Disability Committee's adverse finding against Australia in relation to Marlon Noble, an Aboriginal man found unfit to stand trial in Western Australia because of his intellectual disability. ${ }^{22}$ On 23 September 2016, the Disability Committee found that Australia breached its obligations under the CRPD by subjecting Mr Noble to indefinite detention under the CLMIA Act, and asked Australia to, among other things, take measures to prevent similar violations by amending the CLMIA Act and any equivalent or related laws. To date, neither the Western Australian Government nor the Australian Government has responded.

The CRPD does not 'explicitly define' disability or impairment, but ostensibly adopts a social model of disability, recognising that disability is an 'evolving concept' resulting from interaction with external barriers. ${ }^{23}$ Article 1 contains a non-exhaustive definition of '[p] ersons with disabilities', which includes persons who have 'long-term ... mental ... impairments which in interaction with various barriers may hinder their full and effective participation in society on an equal basis with others' ${ }^{24}$ The 'social model of disability' broadly captures a theory of disability that arose out of the disability rights movement in the $1960 \mathrm{~s}$, and responds to the dominant medical model of disability. ${ }^{25}$ The social model distinguishes between impairment and disability; the former referring to 'functional limitation within the individual caused by physical, mental or sensory impairment,' the latter to 'physical and social barriers' to participation. ${ }^{26}$

20 Human Rights (Parliamentary Scrutiny) Act 2011 (Cth).

21 Human Rights Council, Report of the Working Group on the Universal Periodic Review: Australia, 31st sess, Agenda Item 6, UN Doc A/HRC/31/14 (13 January 2016).

22 Committee on the Rights of Persons with Disabilities, Views: Communication No 7/2012, 16th sess, UN Doc CRPD/C/16/D/7/2012 (2 September 2016); Fiona McGaughey et al, 'UN Decision on Marlon Noble Case: Imprisonment of an Aboriginal Man with Intellectual Disability Found Unfit to Stand Trial in Western Australia' (2017) 42(1) Alternative Law Journal 67.

23 CRPD Preamble; Shivaun Quinlivan, 'The United Nations Convention on the Rights of Persons with Disabilities: An introduction' (2012) 13(1) ERA Forum 71; Rosemary Kayess and Phillip French, 'Out of Darkness into Light? Introducing the Convention on the Rights of Persons with Disabilities' (2008) 8 Human Rights Law Review 1, 21.

24 CRPD Art 1.

25 See Michael Oliver, Understanding Disability: From Theory to Practice (Macmillan, 1996). For discussion of the critiques of this model, see Dimitris Anastasiou and James M Kauffman 'The Social Model of Disability: Dichotomy between Impairment and Disability' (2013) 38(4) Journal of Medicine and Philosophy 44; Kayess and French, above n 23.

26 Colin Barnes, Disabled People in Britain and Discrimination: A Case for AntiDiscrimination Legislation (C Hurst \& Co, 1991) 2. 
This model 'locates the experience of disability in the social environment, rather than impairment, and carries with it the implication of action to dismantle the social and physical barriers to the participation and inclusion of persons with disability'. ${ }^{27}$ While, as a product of negotiation, the CRPD does not completely adhere to the social model in its provisions, it is embodied in the CRPD and founds the 'paradigm shift' that the CRPD is said to represent.

Importantly, the CRPD obliges State Parties to 'prohibit all discrimination on the basis of disability' and to 'guarantee to persons with disabilities equal and effective legal protection against discrimination'. ${ }^{28}$ The Preamble expresses concern about the multiple forms of discrimination experienced by persons with disabilities, including on the basis of indigenous origin. States parties are also required to ensure 'reasonable accommodation' is provided so that persons with disabilities can exercise and enjoy all human rights and freedoms on an equal basis with others, ${ }^{29}$ including access to justice. ${ }^{30}$ The UNDRIP also requires states to take effective measures to ensure the continuing improvement of Indigenous peoples' economic and social conditions, particularly Indigenous persons with disabilities. ${ }^{31}$

In line with the social model, the CRPD stresses equality and participation. Whilst the International Covenant on Civil and Political Rights $(\mathrm{ICCPR})^{32}$ already entitles persons with disabilities to equal recognition before the law, ${ }^{33}$ Art 12 of the CRPD obliges states to take positive action to ensure persons with disabilities have access to support to assist with their exercise of legal capacity. ${ }^{34}$ It also requires states to put safeguards in place to protect the 'right, will and preference of the person' and ensure that support is not abused..$^{35}$ The UNDRIP, too, reaffirms the right to participate in decision-making. ${ }^{36}$

The Disability Committee has stated that domestic mental health laws may need to be reformed in order to comply with Art 12,37 emphasising that a disability or impairment (whether physical or sensory) 'must never' justify the removal or limitation of legal capacity. ${ }^{38}$ The Office of the United

$27 \quad$ Kayess and French, above n 23, 6.

28 CRPD Art 2.

29 Ibid.

30 Ibid Art 13.

31 UNDRIP Art 21.

32 International Covenant on Civil and Political Rights, opened for signature 16 December 1966, 999 UNTS 171 (entered into force 23 March 1976) (ICCPR).

33 Ibid Art 16.

34 This right is non-derogable: Committee on the Rights of Persons with Disabilities, General Comment No 1: Article 12: Equal Recognition before the Law, 11th sess, UN Doc CRPD/C/GC/1 (11 April 2014) [5] (General Comment No 1).

35 CRPD Art 12(4).

36 United Nations Inter-Agency Support Group on Indigenous Peoples Issues, Thematic Paper on the Rights of Indigenous Peoples/Persons with Disabilities (2014).

37 General Comment No 1, above n 34, [7].

38 Ibid [9]. 
Nations High Commissioner for Human Rights (UN Commissioner) has interpreted Art 12 as requiring states to abolish any criminal law that negates criminal responsibility due to 'mental or intellectual disability' (such as the 'insanity defence') and encourages the adoption of 'disabilityneutral' doctrines regarding mens rea. ${ }^{39}$ The UN Commissioner advocates the introduction of disability-neutral doctrines that take into account the 'situation of the individual defendant', ${ }^{40}$ as opposed to existing measures that justify the limitation of an individual's legal capacity on the basis of actual or perceived deficiencies in mental capacity. ${ }^{41}$

Upon ratifying the $\mathrm{CRPD}$, Australia issued an interpretative declaration to Art 12. Australia declared its understanding that Art 12 allows the use of 'fully supported or substituted decision-making arrangements', as well as 'compulsory assistance or treatment' of persons with disabilities, as a last resort when such arrangements or treatment are necessary and subject to safeguards. ${ }^{42}$ The Disability Committee has recommended that Australia review the interpretive declaration, in order to withdraw it. ${ }^{43}$

Echoing Art 9 of the ICCPR, Art 14 of the CRPD asserts the right to liberty and security of the person, and specifically prohibits deprivation of liberty based on a disability in any circumstances. ${ }^{44}$ Article 14(1)(b)

39 Office of the United Nations High Commissioner for Human Rights, Thematic Study by the Office of the United Nations High Commissioner for Human Rights on Enhancing Awareness and Understanding of the Convention on the Rights of Persons with Disabilities, 10th sess, Agenda item 2, UN Doc A/HRC/10/48 (26 January 2009) 15 [47] (Thematic Study).

40 Ibid.

41 General Comment No 1, above n 34, [13].

42 Convention on the Rights of Persons with Disabilities: Declarations and Reservations (Australia), opened for signature 30 March 2007, 999 UNTS 3 (entered into force 3 May 2008). Whether the CRPD permits substituted decision-making at all is unclear: see, for example, Tina Minkowitz, 'Abolishing Mental Health Laws to Comply with CRPD' in Bernadette McSherry and Penny Weller (eds), Rethinking Rights-Based Mental Health Laws (Hart Publishing, 2010) 151; Nandini Devi et al, 'Moving Towards Substituted or Supported Decision-Making? Article 12 of the Convention on the Rights of Persons with Disabilities' (2011) 5 ALTER - European Journal of Disability Research 249; Bernadette McSherry, 'Legal Capacity under the Convention on the Rights of Persons with Disabilities' (2012) 20 Journal of Law and Medicine 22; Piers Gooding, 'Supported Decision-Making: A Rights-Based Disability Concept and its Implications for Mental Health Law' (2013) 20(3) Psychiatry, Psychology and Law 431.

43 Committee on the Rights of Persons with Disabilities, Concluding Observations on the Initial Report of Australia, 10th sess, UN Doc CRPD/C/AUS/CO/1 (21 October 2013) [9] (Concluding Observations).

44 Proposals made during the drafting of Art 10 (now 14) suggested it read 'based solely on disability'. This was ultimately rejected and thus the application of Art 14 is much broader: Ad Hoc Committee on a Comprehensive and Integral International Convention on the Protection and Promotion of the Rights and Dignity of Persons with Disabilities, Report of the Third Session of the Ad Hoc Committee on a Comprehensive and Integral International Convention on the Protection and Promotion of the Rights and Dignity of Person with Disabilities, 3rd sess, UN Doc A/AC.265/2004/5 (9 June 2004) 24. 
provides that the 'existence of a disability shall in no case justify a deprivation of liberty'. ${ }^{45}$ The UN Commissioner has interpreted this prohibition to cover instances in which disability is the only basis for the deprivation of liberty, and circumstances where a deprivation of liberty has occurred due to a disability in combination with other factors, such as treatment, care or protection of the public. ${ }^{46}$ Interpreted in this way, Art 14 significantly extends the protection contained in Art 9 of the ICCPR in circumstances where a deprivation of liberty is based on mental impairment.

Article 13 of the CRPD requires states parties to ensure persons with disabilities have 'effective access to justice ... on an equal basis with others'. ${ }^{47}$ States parties should facilitate access by providing 'procedural ... accommodations' to 'direct and indirect participants ... in all legal proceedings' and 'appropriate training' for individuals working in the criminal justice system, 'including police and prison staff'. ${ }^{48}$ The 2013 Study by the Permanent Forum on Indigenous Issues found that:

[T] he general justice system needs to be accessible to persons with disabilities and also sensitive to indigenous persons with disabilities. Disability awareness training, with rights-based and intercultural approaches, needs to be provided to staff in charge of the administration of justice. ${ }^{49}$

The duty to accommodate in this context should be understood as 'the duty of a public or private entity to make the modifications or changes that are required by a person with a disability ... to ensure the equal access of the person to the service or to the activity'. ${ }^{50}$ The Disability Committee has urged all Australian States and Territories to amend current legislation in order to implement the requirements contained in Art $13 .^{51}$

If these provisions are implemented in line with current interpretations from the Disability Committee and UN Commissioner, this will radically change the conceptualisation of mental impairment in criminal law and its use as a determinative factor in the criminal justice system. The following section examines the place of the CRPD in reforming the Western Australian fitness to stand trial regime, with a particular focus on Indigenous young people with FASD.

\section{Fitness to Stand Trial in Western Australia}

The CLMIA Act was introduced in 1996 to modernise Western Australian law relating to the treatment of accused persons with mental impairment

\footnotetext{
45 (emphasis added).

46 Thematic Study, above n 39, 15 [48].

47 CRPD Art 13.

48 Ibid.

49 Permanent Forum on Indigenous Issues, above n 16, 32 [9].

50 Thematic Study, above n 39, 13 [39].

51 Concluding Observations, above n 43, 4.
} 
in the criminal justice system. ${ }^{52}$ This was much needed reform: the law relating to mental fitness to stand trial had remained unchanged since 1913. Before the CLMIA Act, fitness to stand trial was governed by s 631 of the Criminal Code (WA), which provided that incapacity could arise 'for any reason'- it need not relate to mental impairment. ${ }^{53}$

The CLMIA Act was introduced following several reviews of the law governing mental disorders and the criminal process. ${ }^{54}$ It introduced a definition of mental impairment, to mean intellectual disability, mental illness, brain damage or senility, ${ }^{55}$ and provided that fitness decisions be made by a judicial officer, rather than a jury. In his second reading speech to the Criminal Law (Mentally Impaired Defendants) Bill 1996 (WA), Attorney-General Peter Foss said:

[T] he Government remains committed to the paramount goal of a safe and secure environment for all Western Australians while ensuring that all participants in the criminal justice system are treated fairly and equitably and the process itself is cost efficient and effective. ${ }^{56}$

The CLMIA Act enshrines the common law 'presumption' of fitness to stand trial in s 10. The presumption is displaced by proof, on the balance of probabilities, that the accused is unfit to stand trial. ${ }^{57}$ The issue of fitness may be raised at any stage of the proceedings by the defence, prosecution or the court. ${ }^{58}$ The presiding judicial officer determines whether an accused is unfit to stand trial after conducting inquiries and informing himself or herself in any way the judicial officer thinks fit. ${ }^{59}$ For example, they may order the accused be examined 'by a psychiatrist or other appropriate expert'. ${ }^{60}$

If an accused is found unfit to stand trial in a court of summary jurisdiction, the court has two options - if satisfied that the accused will not become fit within six months, the court may dismiss the charge and release the accused or make a custody order. ${ }^{61}$ There is no intermediate option akin to a community release order. Custody orders apply indeterminately as there is no requirement for a limiting term to be made, in contrast to other Australian jurisdictions. ${ }^{62}$ The court may only make a custody order

$52 \quad$ Western Australia, Parliamentary Debates, Legislative Council, 5 November 1996, 771 (Peter Foss, Attorney General).

53 See Ngatayi $v$ The Queen (1980)147 CLR 1. Section 631 was based on $R v$ Pritchard (1836) 7 C\&P 303; 173 ER 135.

54 Most notably, the Law Reform Commission of Western Australia, The Criminal Process and Persons Suffering from Mental Disorder, Report 96 (1991).

55 Criminal Law (Mentally Impaired Accused) Act 1996 (WA) s 8 (CLMIA Act).

56 Western Australia, Parliamentary Debates, Legislative Council, 5 November 1996, 771 (Peter Foss, Attorney-General).

57 CLMIA Act s 12 (1).

58 Ibid s 11(2).

59 Ibid s 12(1).

60 Ibid s 12(2)(a).

61 Ibid ss 16(2)(a), 16(5).

62 See, for example, Crimes Act 1900 (ACT) ss 301-306; Criminal Law Consolidation Act 1935 (SA) s $2690(2)$. 
if the penalty for the alleged offence includes imprisonment and the court is satisfied that a custody order is the appropriate course of action. ${ }^{63} \mathrm{In}$ making this determination, the court must consider the strength of the available evidence, the nature of the offence, the circumstances surrounding its commission, the personal characteristics of the accused, and the public interest. ${ }^{64}$ If unsatisfied that the accused will become fit to stand trial, the court may adjourn the proceedings for any period, not exceeding six months, to see if the accused becomes fit. ${ }^{65}$ The procedure is similar for indictable offences. The only difference is if a court of summary jurisdiction dismisses the charge, the accused cannot be charged again or tried for the same offence. ${ }^{6}$ For indictable offences, an accused may be indicted, or indicted again, and tried for the same offence. ${ }^{67}$

Despite recent attempts to substantially reform the CLMIA Act, ${ }^{68}$ extensive criticism from the legal community, ${ }^{69}$ the media and public, ${ }^{70}$ and reviews of similar legislation in almost all other Australian jurisdictions, ${ }^{71}$ its provisions have remained largely unchanged. The Western Australian Attorney-General's Department recently reviewed the CLMIA Act. ${ }^{72}$ When tabling the Final Report of the Review (2016 Review) in Parliament, the Attorney-General indicated his intention to 'take to cabinet a package of reforms based on the recommendations of the report'. ${ }^{73}$ The recommendations of the 2016 Review would, if implemented, overcome some - but not all - of the deficiencies of the regime.

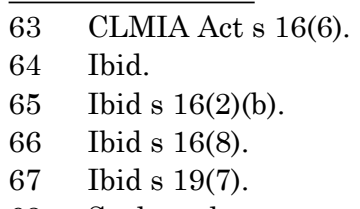

68 Such as the unsuccessful Private Members Bill introduced by John Quigley MLA in 2014: Criminal Law (Mentally Impaired Accused) Amendment Bill 2014 (WA).

69 Western Australia v BB (A Child) [2015] WADC 2, 16 [55] (Reynolds J); Western Australia v Tax [2010] WASC 208, [18]-[19] (Martin CJ); Australian Law Reform Commission (ALRC), Equality, Capacity and Disability in Commonwealth Laws, Report 124 (2014); Blagg et al, 'Diversionary Pathways', above n 8; Catherine Crawford, 'Families Impacted by the Criminal Justice System on the Frontier: A New Model Required' (2010) 17(3) Psychiatry, Psychology and Law 464; Office of the Inspector of Custodial Services of Western Australia, Mentally Impaired Accused on 'Custody Orders': Not Guilty, But Incarcerated Indefinitely (2014).

70 See, for example, Jacob Kagi, 'Mentally-Impaired Accused Deemed Unfit to Stand Trial Could Be Treated Alongside Prisoners in WA', $A B C$ News (online), 25 June 2015 <http://www.abc.net.au/news/2015-06-25/ mentally-impaired-accused-could-be-treated-alongside-prisoners/6572274>.

71 See, for example, Victorian Law Reform Commission, Review of the Crimes (Mental Impairment and Unfitness to be Tried) Act 1997, Report 28 (2014); ALRC, above n 69, 194-210; New South Wales Law Reform Commission, People with Cognitive and Mental Health Impairments in the Criminal Justice System: Criminal Responsibility and Consequences, Report 38 (2013).

72 Department of the Attorney General (WA), Review of the Criminal Law (Mentally Impaired Accused) Act 1996, Final Report (2016) (2016 Review).

73 Western Australia, Parliamentary Debates, Legislative Council, 7 April 2016, 2247 (Michael Mischin, Attorney-General). 
Submissions to the Review couched some concerns with the regime in terms of its contravention of the rights contained in the CRPD - primarily in relation to indefinite detention. ${ }^{74}$ As we outline below, the CRPD might be relied upon by those advocating reform to address concerns regarding the test of unfitness; the absence of a trial or special hearing process to determine the accused's guilt or innocence; the limited options available when a court finds a person unfit to stand trial: (unconditional release or a custody order where imprisonment is a sentencing option); and the unlimited duration of a custody order. However, as noted, a cautious assessment of the likely impact of the CRPD is called for, given the reluctance of successive Australian governments to comply with core international human rights instruments. ${ }^{75}$

\section{The Fitness Test And Supports}

Pursuant to s 9, an accused is mentally unfit to stand trial if, 'because of mental impairment', they are 'unable to understand' the nature of the charge or the purpose of the trial; the requirement to plead or effect of a plea; or are unable to follow the trial, understand evidence, challenge jurors or properly defend the charge. These factors, based on those expressed by Smith J in $R v$ Presser, ${ }^{76}$ have received criticism. Several recent reviews of the criteria in other Australian jurisdictions have questioned whether they should be amended as they disproportionately focus on the accused's intellectual ability as opposed to their decision-making ability. ${ }^{77}$ The 2016 Review evaluated the criteria and recommended s 9 be amended so as to include the accused's ability to instruct legal counsel, to decide whether to give evidence in court and ability to give evidence if they choose to. ${ }^{78}$ The Disability Committee has criticised this type of 'functional' approach to assessing 'mental capacity'. ${ }^{79}$

\section{Legal Capacity and Mental Capacity}

The Disability Committee distinguishes between legal and mental capacity. It defines legal capacity as the 'ability to hold rights and duties (legal standing)' and the ability 'to exercise those rights and duties (legal agency)' ${ }^{80}$ while mental capacity refers to an individual's decision-making

742016 Review, above n 72, 74-75.

75 Human Rights Council, above n 21.

76 [1958] VR 45, 48.

77 ALRC, above n 69, [7.19].

782016 Review, above n 72, 49.

79 General Comment No 1, above n 34, [15]. For possible alternatives to the functional approach, see Tina Minkowitz, 'Rethinking Criminal Responsibility from a Critical Disability Perspective: The Abolition of Insanity/Incapacity Acquittals and Unfitness to Plead, and Beyond' (2014) 23(3) Griffith Law Review 434; Slobogin, above n 12.

80 General Comment No 1, above n 34, [13]. 
skills or abilities. ${ }^{81}$ The Disability Committee's commentary on mental capacity identifies that it is a 'controversial concept' that is neither objective nor scientific, but in fact relies upon social and political factors. ${ }^{82}$ Article 12 of the CRPD prohibits any 'perceived or actual deficits in mental capacity' justifying the limitation or denial of legal capacity. ${ }^{83}$ The Disability Committee is especially critical of the use of the 'functional approach' to assess mental capacity; this approach considers an individual's ability to 'understand the nature and consequences of a decision' and/or their ability to 'use or weigh' relevant information. ${ }^{84}$ It perceives this approach as misleading in its purported ability to accurately assess an individual's competency in order to limit their legal capacity and right to 'equal recognition before the law'. 85

Section 9 of the CLMIA Act arguably infringes the accused's nonderogable right to equal recognition before the law as the court, through conducting a functional assessment, is using mental capacity as a justification to limit the accused's legal capacity to defend themselves. According to the Disability Committee's interpretation, while the accused might suffer from actual deficits in mental capacity, this is not a valid justification for limiting or denying legal capacity pursuant to the CRPD.

As noted above, the UN Commissioner has also considered the impact of Art 12 in the criminal law context. The Commissioner found that the realisation of legal capacity requires states parties to abolish any 'defence based on the negation of criminal responsibility because of the existence of a mental or intellectual disability'. ${ }^{86}$ This could logically extend to fitness to stand trial laws as they similarly rely on the 'existence of a mental or intellectual disability' to limit legal capacity, specifically the accused's legal agency. ${ }^{87}$ While such doctrines are designed to protect the accused's right to a fair trial, they rely upon disability as the basis for limiting the accused's human rights, which is arguably discriminatory. ${ }^{88}$ If the Commissioner's approach is followed, fitness laws will need to be abolished in favour of 'disability-neutral doctrines'.

However, a conflict arises if this approach is adopted. While the intention is to ensure equality and eliminate discrimination, removing mental capacity as a determinative factor in fitness provisions may infringe the accused's right to a fair trial. Such laws are an essential protection for individuals with mental impairment who are charged with a crime, as they ensure an accused will only stand trial if they are in a position to adequately defend themselves. ${ }^{89}$ The concept of mental capacity is

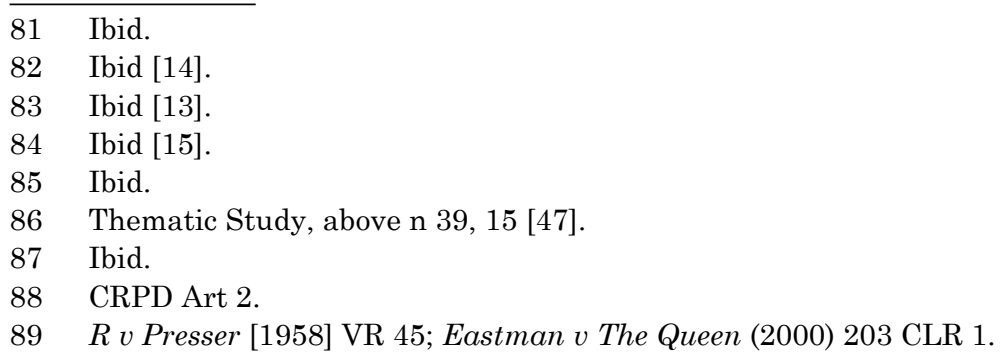


inextricably linked to criminal responsibility and procedure; it is difficult to envision its removal in a manner that does not detrimentally affect persons with mental impairment. The Australian Law Reform Commission recently expressed a similar view when reviewing the impact of the CRPD domestically: 'the integrity of a criminal trial (and, arguably, the criminal law itself) would be prejudiced if the defendant does not have the ability to understand and participate in a meaningful way'. ${ }^{90}$

Bartlett regards this movement away from mental impairment as 'counter-intuitive'. ${ }^{91}$ Developing disability-neutral doctrines of criminal responsibility that take into account the 'situation' of the accused will likely still result in a determination based on the accused's mental capacity and thus likely contravene Art 12 . While the criteria for establishing mental fitness can be removed, the determination that an accused with mental impairment is unable to adequately conduct their own defence will still be 'directly associated with their mental disability'. ${ }^{92}$ In the process, less protection will be offered to vulnerable individuals in the criminal justice system; a system that already over-represents persons with mental impairment.

The formulation of disability neutral doctrines may also be counterproductive for Indigenous youth with FASD. FASD, the intergenerational impact of long-term alcohol use, is increasingly recognised as a symptom of colonisation and its legacy. ${ }^{93}$ The collateral damage of colonial dispossession manifests in intergenerational trauma, family violence, alcohol-related harms and youth suicide, creating what Atkinson describes as the 'trauma to prison pipeline'. ${ }^{94}$ Disability neutrality may have the undesired effect of denying the colonial underpinnings of disability in Indigenous communities, and rendering culture invisible.

Rather, consideration must be had to 'appropriate and effective safeguards' that can be put in place to facilitate a mentally impaired accused's participation in the criminal justice system on an equal basis with others. The Disability Committee has advocated the use of supported decision-making to assist those with mental impairment to exercise their legal capacity to the greatest extent possible. ${ }^{95}$ Support is provided by a nominated person who 'explain(s) the issues, when necessary, and interpret(s) the signs and preferences of the individual' ${ }^{96}$ The 2016 Review did recommend the CLMIA Act be amended so to 'expressly

$90 \quad$ ALRC, above n 69, 73 [3.45].

91 Bartlett, above n 10, 776.

92 Ibid.

93 See, for example, comments of Cozens J in $R v$ Quash [2009] YKTC 54, [62].

94 Judy Atkinson, Trauma-Informed Services and Trauma-Specific Care for Indigenous Australian Children, Resource Sheet 21, (Australian Institute of Health and Welfare, 2013); see also, Judy Atkinson, Trauma Trails, Recreating Song Lines: The Transgenerational Effects of Trauma in Indigenous Australia (Spinifex Press, 2002).

95 General Comment No 1, above n 34, 6-7.

96 United Nations Department of Economic and Social Affairs, United Nations Office of the High Commissioner for Human Rights and Inter-Parliamentary Union, 
provide that the Court may order modifications to court processes to assist an accused person ${ }^{9}{ }^{97}$ In this way, the CRPD could be used to agitate for greater assistance for a mentally impaired individual to participate in the trial process and thereby avoid the operation of mentally impaired accused legislation.

\section{Absence of a Special Hearing}

Special hearings were introduced in Australian jurisdictions because unfit accused did not otherwise have a trial or 'opportunity for acquittal'. ${ }^{98}$ In jurisdictions with special hearings, an unfit accused is only subject to the coercive provisions of the regime if found to have engaged in the conduct constituting the offence. The benefit of a special hearing mechanism is that the evidence against an accused is tested and subject to adversarial challenge. An unfit accused is afforded, as far as is possible, the benefit of the presumption of innocence and the heightened procedural and evidentiary requirements of the accusatorial trial process - and the possibility of acquittal. The 2016 Review considered the introduction of a special hearing and found that it could not be 'justified'. ${ }^{99}$ Alternatively, it recommended the requirement that the judicial officer 'have regard to whether there is a case to answer on the balance of probabilities' after conducting an inquiry. ${ }^{100}$

The principles contained in the CRPD likely support the introduction of a special hearing mechanism - and could be relied upon in advocacy for legal change. The CLMIA Act does require the court to consider the 'strength of the available evidence'; ${ }^{101}$ however, the absence of a special hearing means that any subsequent detention of a mentally impaired accused is based upon the presence of a 'mental impairment', a substantially untested 'allegation' 102 that the accused has committed the offence, and the public interest. This contravenes the UN Commissioner's interpretation of Art 14(1)(b). Using a special hearing to determine whether an accused committed the charged conduct would likely provide some justification for detention. A special hearing may also be considered a necessary '[p]rocedural accommodation' ${ }^{103}$ to ensure a mentally impaired accused enjoys the equal protection of the law (primarily, the right to a fair trial) and effective access to justice, as required by the CRPD. The Disability Committee has recommended accused persons with disabilities

From Exclusion to Equality: Realizing the Rights of Persons with Disabilities, Handbook 14 (2007) 89-90.

972016 Review, above n 72, 9.

98 New South Wales Law Reform Commission, above n 71, 141.

992016 Review, above $\mathrm{n} 72$, [133].

100 Ibid [139].

101 CLMIA Act ss 16(6), 19(5).

102 Criminal Procedure Act 2004 (WA) s 3 (definition of 'charge').

103 Thematic Study, above n 39, [47]. 
currently detained without trial in Australia be given the opportunity to defend themselves, with the assistance of appropriate 'support and accommodation to facilitate their effective participation'. ${ }^{104}$

\section{Options Available to the Court on a Finding of UnFITNESS}

In Western Australia $v$ Tax, Martin CJ identified that only having two choices upon a finding of unfitness, unconditional release or indefinite custody, was a significant deficiency in the Act. ${ }^{105}$ The choice of two extreme options does not provide the court with the 'range of remedies' needed to deal with this 'complex and multifaceted' situation. ${ }^{106}$ Reynolds J, President of the Children's Court, echoed these sentiments in Western Australia v BB (A Child), commenting that 'the legislation in its current form puts undue pressure on legal advisers to go down the path of arguing that an accused is unfit to stand trial in order to avoid exposing the accused to the possibility of an indefinite custody order'. ${ }^{107}$ Reynolds J called for urgent reform of the CLMIA Act in order to 'give [c]ourts more options'. ${ }^{108}$

The introduction of 'community-based' orders has been suggested as a remedy. ${ }^{109}$ The 2016 Review recommended that the options available to a court be expanded to include the range of orders 'available under the Sentencing Act 1995, subject to any necessary amendments required to clarify that the accused has not been convicted of an offence'. ${ }^{110}$ The Review further recommended that 'a broader range of options to be made available for juveniles found mentally unfit to stand trial, modelled on the sentencing options under Part 7 of the Young Offenders Act 1994. ${ }^{111}$ For young persons, Pt 7 of the Young Offenders Act 1994 (WA) (YOA) includes the options of an intensive youth supervision order, a youth community based order or a conditional release order.

While this is an important recommendation, and undoubtedly improves the current regime, the problematic nature of such orders has been noted in the context of Indigenous youth who are fit to stand trial. ${ }^{112}$ The overrepresentation of Indigenous youth in Western Australia's justice system has only worsened since the introduction of 'community-based' orders in

104 Concluding Observations, above n 43, 4-5.

105 Western Australia v Tax [2010] WASC 208, [17]-[18].

106 Ibid.

107 Western Australia v BB (A Child) [2015] WADC 2, [55].

108 Ibid.

109 See, for example, Inspector of Custodial Services of Western Australia, above n 69,10 .

1102016 Review, above n 72, 10.

111 Ibid 157.

112 Harry Blagg, Crime, Aboriginality and the Decolonization of Justice (Federation Press, 2008) 183. 
the YOA. ${ }^{113}$ It is also important to note that for youth community-based orders, ${ }^{114}$ a young person must consent to the order. Even if an unfit youth with FASD has the capacity to consent to an order, research indicates that the difficulties a young person with FASD may have with memory and linking actions to consequences may mean that they are unable, rather than unwilling, to comply with court orders. ${ }^{115}$

These difficulties have also been highlighted by the courts. For example, Reynolds J stated in $B B$ :

There are also systemic challenges in relation to the management of Court orders under the YO Act in cases such as BB's. The idea that for someone like $\mathrm{BB}$, supervision by telephone would be meaningful and have the real potential to produce behavioural change is misplaced. In addition to that, giving warning letters to young persons with mental impairment and/or no ability to read is simply process for the sake of process. It is not something that a Court would rely on. ${ }^{116}$

Failure to comply with community-based orders may result in charges for breach and compound a young person with FASD's criminal history, rendering them more susceptible to a custody order under the YOA. Community-based orders may therefore be counterproductive for youth with FASD.

The CRPD might be relied upon to address some of these concerns, but it does not fully resolve them. The Disability Committee has also recommended that states parties establish 'mandatory guidelines and practice to ensure that persons with disabilities in the criminal justice system are provided with appropriate supports and accommodation'. ${ }^{117}$ Departing from contemporary practice, the Disability Committee has also recommended that diversion programs which require individuals to participate in mental health 'commitment regimes' or 'services' without 'free and informed consent' be abolished. ${ }^{118}$ The Human Rights Committee (HRC) has considered detention in relation to mental health, advocating that states parties have 'adequate community-based or alternative social care services for persons with psychosocial disabilities' to avoid confinement. ${ }^{119}$

Fundamentally, 'community-based' orders are inadequate because they are 'community-based' rather than 'community-owned' solutions. ${ }^{120}$

113 Loh Nini Sui Nie et al, Crime and Justice Statistics for WA: 2005, Report (Crime Research Centre, University of Western Australia, 2005) 43.

114 Young Offenders Act 1994 (WA) s 74.

115 Douglas, above n 5, 228; Education and Health Standing Committee, above n 6, 76.

116 Western Australia v BB (A Child) [2015] WADC 2, [78]-[79].

117 Thematic Study, above n 39, [39].

118 Ibid [29].

119 Human Rights Committee, General Comment No 35: Article 9 (Liberty and Security of Person), 112th sess, UN Doc CCPR/C/GC/35 (16 December 2014) [19] (General Comment No 35).

120 Harry Blagg, A New Way of Doing Justice Business: Community Justice Mechanisms in Western Australia, Background Paper 15 (Law Reform Commission of Western Australia, 2006) 36-37. 
The former are created by government agencies to operate in community settings, while the latter are determined by communities themselves. ${ }^{121}$ To be effective, diversion must promote a positive good by channelling Indigenous youth into non-stigmatising therapeutic alternatives, particularly in the emerging sphere of Indigenous 'on-country' initiatives. A 'decolonising' approach that prioritises and enables diversion into community-owned and managed structures and processes, as opposed to government owned and controlled, if community-based or 'situated', systems has the potential to more adequately address the needs of Indigenous young people with FASD.

\section{Place and Duration of Detention}

If a custody order is made, the Mentally Impaired Accused Review Board (MIARB) determines the place of detention based on the accused's mental impairment. This decision must be made within five days. ${ }^{122} \mathrm{~A}$ mentally impaired accused with a 'treatable' mental illness can be detained in an authorised hospital, provided the treatment is required to 'protect the health and safety of the accused' or another, or prevent serious property damage. ${ }^{123} \mathrm{~A}$ mentally impaired accused with intellectual impairment is eligible to be held in a 'declared place' established by the Disability Services Commission. ${ }^{124}$ Until recently, such a place did not exist and intellectually or cognitively impaired accused were held in prisons, or juvenile detention centres if under 18 years of age. With the passage of the Declared Places (Mentally Impaired Accused) Act 2015 (WA), the Disability Services Commission has established a 'declared place': the Bennett Brook Disability Justice Centre. However, the Centre has less than 10 beds and does not cater for children under 16 years of age. ${ }^{125}$

A number of submissions to the 2016 Review addressed the inadequacies of detaining mentally impaired accused in a prison setting, particularly regarding the availability and suitability of programs and services. The 2016 Review did not, however, recommend the abolition of prison as a place for detaining mentally impaired accused. The Review noted that in regional areas, prison may provide the only secure facility proximate to family and community. ${ }^{126}$ The Review found that a 'constructive response to concerns' was to focus on improving the provision and coordination of services to mentally impaired accused detained in prison, and the training of custodial staff. ${ }^{127}$ The Disability Committee has

\footnotetext{
121 Ibid 318.

122 CLMIA Act s 25(1).

123 Ibid s 24(3).

124 Ibid s 24(5A).

125 WA Disability Services Commission, Bennett Brook Disability Justice Centre <http://www.disability.wa.gov.au/reform1/reform/disability-justice-centre/>.

1262016 Review, above n 72, [307].

127 Ibid [308].
} 
recommended that Australia, 'as a matter of urgency', stop using prisons to manage persons with disabilities found unfit to stand trial. ${ }^{128}$

A person subject to a custody order will be detained until released by an order of the Governor (in practice, on the recommendation of the MIARB). ${ }^{129}$ The only protection against an accused's indefinite detention is the Board's reporting requirements under the CLMIA Act. ${ }^{130}$ Mentally impaired accused are thus in a perpetual state of uncertainty regarding their fate - as stated by an individual held under the Act: 'I just want a date. Everyone else has a date. It's not fair.' ${ }^{331}$

The Disability Committee has expressed concern about the indefinite detention of mentally impaired accused, stating in relation to Australia's implementation of Art 14:

The Committee is concerned that persons with disabilities, who are deemed unfit to stand trial due to an intellectual or psychosocial disability can be detained indefinitely in prisons or psychiatric facilities without being convicted of a crime, and for periods that can significantly exceed the maximum period of custodial sentence for the offence. ${ }^{132}$

The Disability Committee was specifically concerned with the over-representation of 'persons with disabilities' in prison and juvenile detention, in particular Indigenous Australians with disability. ${ }^{133}$

It is not only detention after an order that is problematic. A young person may be remanded in custody while their fitness is investigated. In $B B$, Reynolds $\mathrm{J}$ lamented the length of time the young person spent on remand - 30 December 2013 to 4 April 2014 - in order for fitness to be investigated: '[i]t is a long time for a young person and particularly for a young Aboriginal person being away from country and family and suffering from mental impairment.' ${ }^{134}$ The HRC asserts that remand must be 'reasonable, and necessary in all the circumstances'. ${ }^{135}$ The period of detention before reaching trial should not be longer than could have been imposed for the crimes charged - if such a period is expended, the accused should be released. ${ }^{136}$ The HRC explains the justification for the accused being tried without undue delay as to ensure the accused is not kept 'too long in a state of uncertainty about their fate', to ensure that any deprivation of liberty does not last longer than is necessary and to 'serve the interests of justice'. ${ }^{137}$

128 Concluding Observations, above n 43, [31].

129 CLMIA Act s 24.

130 Ibid ss 33-34.

131 Inspector of Custodial Services of Western Australia, above n 69, i.

132 Concluding Observations, above n 43, [31].

133 Ibid.

134 Western Australia v BB (A Child) [2015] WADC 2, [82]. The period served on remand is to be taken into account by the court in deciding whether to make a custody order: Western Australia v Sanders [2012] WASC 209.

135 General Comment No 35, above n 119, [12].

136 Ibid [38].

137 Human Rights Committee, General Comment No 32: Article 14: Right to Equality before Courts and Tribunals and to a Fair Trial, 19th sess, UN Doc CCPR/C/GC/32 (23 August 2007) [35]. 
The 2016 Review recommended the retention of indefinite custody orders for unfit accused, emphasising that the preventive, protective and therapeutic purposes of detention under the CLMIA Act are inconsistent with fixed terms. ${ }^{138}$ The 2016 Review did, however, recommend the establishment of a working group to review the operation of indefinite custody orders, ${ }^{139}$ and that further consideration be given to 'developing juvenile-specific considerations' in deciding whether or not to recommend release. ${ }^{140}$

If custody orders are retained, the CRPD might be relied upon to strengthen arguments for periods of detention that do not extend beyond the period the accused would have received if found guilty. Further, the CRPD might be relied upon to agitate for mentally impaired accused to be afforded the right to 'initial and periodic' judicial review of a custody order, ${ }^{141}$ as opposed to the executive discretion model that is currently in place.

\section{Human Rights, Disability and Indigeneity}

The CRPD can inform the 'duties, obligations and responsibilities' of government and society to mentally impaired accused - and as such provide an important resource for those advocating domestic legal change. The CRPD is, however, limited in what it can achieve at the domestic level, even if implemented in legislation. Australia's pragmatic interpretation of Art 12, which appears to be at odds with the principles of the CRPD, is a good example. Australia has not taken any action in response to the Disability Committee's recommendation that Australia review its interpretive declaration in order to withdraw it. Similarly, to date, no action has been taken in response to the Disability Committee's adverse finding against Australia in the Noble case. A limitation of the CRPD is that it "frames disability justice within the realm of the "modern territorial state", reliant upon individual citizens claiming against the nation state. ${ }^{142}$

Indigenous peoples are sceptical about the western human rights agenda underpinning instruments such as the CRPD: they are more likely to agitate for collective Indigenous rights as set out in UNDRIP. UNDRIP is the first human rights instrument drafted 'directly with the rightsholders empowered by the instrument'. ${ }^{143}$ It is, therefore, unlike any other international instrument, reflective of the collective rights and needs of Indigenous peoples - but by no means unproblematic or a panacea. ${ }^{144}$ Both

1382016 Review, above $\mathrm{n} 72$, [227].

139 Ibid [228].

140 Ibid [352].

141 General Comment No 35, above 119, [19].

142 Soldatic, 'The Transnational Sphere of Justice', above n 13, 746.

143 Davis, above n 15, 440.

144 Irene Watson, Aboriginal Peoples, Colonialism and International Law: Raw Law (Routledge, 2014); Irene Watson, 'Aboriginal(ising) International Law and Other Centres of Power' (2011) 20(3) Griffith Law Review 619. 
the CRPD and UNDRIP recognise the intersection between Indigeneity and disability. ${ }^{145}$ As noted, members of the Permanent Forum on Indigenous Issues have stated that the CRPD needs 'to be applied in a way that is sensitive to the culture and world vision of indigenous peoples in order to best protect the rights of indigenous persons with disabilities'. ${ }^{146}$

This requires the CRPD to be read 'in tension' with UNDRIP, with Indigenous knowledge, rather than assume the default position from which all knowledge is measured and tested. This means engaging with the question of Indigenous sovereignty, particularly in the form of demands for the return of land, and the devolution of the care and control of young people to 'community-owned' and 'place-based' Indigenous organisations.

An appropriate response requires decolonising the justice system to break down the innumerable barriers (cultural, structural, psychological and epistemological) that prevent Indigenous people from participating on an equal basis. The social model of disability may be viewed as an important shift towards achieving this, ${ }^{147}$ highlighting that disabilities are a consequence of the interaction between a person's impairments and barriers in the physical, attitudinal, communication and social environment. The 'secondary' disabilities of FASD are the cluster of social and psychological problems that develop because of the barriers to participation and inclusion experienced by persons with FASD. ${ }^{148}$ Research indicates that over 90 per cent of people with FASD will be diagnosed with a psychiatric disorder during their lifetime, ${ }^{149}$ with a third developing substance abuse problems. ${ }^{150}$ Importantly, these 'secondary' disabilities can be prevented or reduced by improving the responsiveness of the justice system and support services to young people with FASD. Improving diversionary pathways out of the criminal justice system is key to reduction in disabilities.

However, the CRPD and the social model of disability can only take us so far. Some of the aspirations of the CRPD regarding disability neutrality may, in fact, be counterproductive for Indigenous young people. The barriers preventing Indigenous people from participating on an equal basis include cultural and structural barriers that form part of the architecture of settler colonialism. Soldatic notes that the

145 UNDRIP Arts 21, 22; CRPD Preamble.

146 Permanent Forum on Indigenous Issues, above n 16, 4.

147 Kayess and French, above n 23, 6.

148 Ann Streissguth and Jonathan Kanter (eds), The Challenge of Fetal Alcohol Syndrome: Overcoming Secondary Disabilities (University of Washington Press, 1997).

149 Kieran O’Malley, 'Fetal Alcohol Spectrum Disorders: An Overview' in Kieran D O'Malley (ed), ADHD and Fetal Alcohol Spectrum Disorders (Nova Science Publishing, 2007) 11.

150 Fred Boland et al, Fetal Alcohol Syndrome: Implications for Correctional Service (Correctional Services Canada, 1998). 
over-representation of impairment amongst Indigenous Australians is a product of, and continuously produced by, the settler state: ${ }^{151}$

It has been suggested that the over-representation of impairment is a reflection of Aboriginal Australians' dispossession, or to use a term from Deborah Rose (2006), a 'double death' - the interstice of white-settler disabling societies and colonizing violence and dispossession - producing impairment and disablement.

At the same time, disability is 'concealed by a discourse of criminality and punishment'. ${ }^{152}$ The social model falters when it is acknowledged that, as in Australia, 'the state remains a disabling force rather than defender of human rights'. ${ }^{153}$

What is needed is a response that decolonises the justice system - and disability ${ }^{154}$ - to break down these barriers to equal participation. Reforms to domestic laws that impact Indigenous youth with FASD should be centred around Indigenous 'place' (or 'country'), and support Indigenousled knowledge and solutions, and community-based services. ${ }^{155}$ Dudgeon et al demonstrate that Aboriginal peoples in Australia see cultural strength and identity as the key to social and emotional wellbeing, and community-led programs as essential to reducing suicide, substance abuse and other health and wellbeing challenges. ${ }^{156}$ Their research reinforces that Aboriginal peoples are best placed to identify the challenges they face and the solutions. For example, the Yiriman Project run out of Fitzroy Crossing by Cultural Bosses has successfully stabilised young people at risk of custody through its cultural immersion work. ${ }^{157}$ This approach does not mean a reduced role for mainstream agencies; indeed, there may be an expanded role for some. Rather, it is intended to create opportunities for collaboration and empowerment.

Our priority should be to employ these systems, not just as ends in themselves, but as points of 'cultural interface' with emerging Indigenousowned and place-based practices and philosophies, and fresh engagement spaces where intercultural dialogue can take place. ${ }^{158}$ For example, Canadian researchers, working with service providers and Indigenous community members, have explored the relationship between trauma and

151 Soldatic, 'Postcolonial Reproductions', above n 13, 64.

152 David Hollinsworth, 'Decolonizing Indigenous Disability in Australia' (2013) 28(5) Disability \& Society 601, 609.

153 Ibid 608; see also Helen Meekosha and Karen Soldatic, 'Human Rights and the Global South: The Case of Disability' (2011) 32(8) Third World Quarterly 1383.

154 Soldatic, 'Postcolonial Reproductions', above n 13; Hollinsworth, above n 152.

155 Eileen Baldry et al, A Predictable and Preventable Path: Aboriginal People with Mental and Cognitive Disabilities in the Criminal Justice System (2015).

156 Pat Dudgeon et al, Voices of the People: The National Empowerment Project: Promoting Cultural Social and Emotional Wellbeing to Reduce Distress and Suicide and in Aboriginal and Torres Strait Islander Communities (2014).

157 Blagg et al, above $\mathrm{n} 8$.

158 Martin Nakarta, 'Indigenous Knowledge and the Cultural Interface: Underlying Issues at the Intersection of Knowledge and Information Systems' (2002) 28 IFLA Journal 5, 5. 
alcohol-use in Northern Canadian Indigenous communities to develop FASD prevention initiatives that 'translate knowledge into meaningful, practical forms that can be shared with, and implemented by, local communities'. ${ }^{159}$

The 1991 Royal Commission into Aboriginal Deaths in Custody remains the 'moral touchstone' for justice reform in Australia, ${ }^{160}$ yet it is, itself, rooted in a colonial worldview and focuses on making extant systems 'work' for Indigenous people, rather than creating new systems. ${ }^{161}$ Should the CRPD serve as the 'touchstone' for disability reform in Australia, it must be acknowledged that it, too, is rooted in an imperial worldview, ${ }^{162}$ containing predominantly individualistic rights and assuming a universal experience of disability that does not acknowledge how disability is negotiated and experienced by Indigenous peoples. ${ }^{163}$ Jaffee highlights:

Both the individualized medical model of disability and a narrowly construed social model ... fail to account for the ways in which disability is entangled with geopolitics and, in particular, how disability injustice is bound up with settler-coloniality. ${ }^{164}$

\section{Conclusion}

This article has examined the place of the CRPD in relation to reforming laws governing fitness to stand trial, with a particular focus on the Western Australian regime and its impact on Indigenous youth with FASD. Many of the aspirations of the CRPD regarding disability neutrality may, we have argued, be counterproductive for Indigenous youth, rendering culture invisible and denying the colonial underpinnings of the disability in Indigenous communities. The CRPD must be read 'in tension' with the UNDRIP and with Indigenous knowledge. This means engaging with the question of Indigenous sovereignty, and the devolution of the care of Indigenous young people to 'community-owned' and 'place-based' Indigenous organisations. An appropriate response requires decolonising the justice system to break down the barriers that prevent Indigenous young people with FASD from participating on an equal basis. To do so,

159 Amy Salmon and Sterling K Clarren, 'Developing Effective, Culturally Appropriate Avenues to FASD Diagnosis and Prevention in Northern Canada' (2011) 70(4) International Journal of Circumpolar Health 428, 431-432.

160 Elena Marchetti and Kathleen Daly, 'Indigenous Courts and Justice Practices in Australia' (2004) 277 Trends and Issues in Criminal Justice 1, 2.

161 Elena Marchetti, 'The Deep Colonising Practices of the Australian Royal Commission into Aboriginal Deaths in Custody' (2006) 33(3) Journal of Law and Society 451.

162 See, for example, Watson, above n 144; Soldatic, 'Postcolonial Reproductions', above n 13; Lauren Benton and Lisa Ford, Rage for Order (Harvard University Press, 2016).

163 JA King et al, 'Negotiating Disability and Colonisation: The Lived Experience of Indigenous Australians with a Disability' (2014) 29(5) Disability \& Society 738.

164 Jaffee, above n 13, 117. 
INDIGENOUS YOUNG PEOPLE WITH FOETAL ALCOHOL SPECTRUM DISORDERS

the role of colonisation in the production of impairment and disability must be acknowledged, and law reform must facilitate community-owned solutions and place Indigenous organisations and practices at the centre of intervention. 